\title{
Sweet chestnut cultures in the Southern Alps - conservation and regional development
}

\section{Oliver Bender}

Keywords: sweet chestnut, Southern Alps, biodiversity, landscape protection, traditional products, socio-economic revitalization, regional development, sustainability

\section{Abstract}

Sweet chestnut cultures are a major component of the vegetation in many large protected areas of the Southern Alps. Since Roman times, vast areas of Southern and Western Europe have been covered by groves and coppices of sweet chestnut trees (Castanea sativa MILL.). Having replaced the original broadleaved forest, they used to play a vital role in traditional agriculture. Chestnut cultivation was even more important in terms of producing a substitute for cereals (bread) than for the production of timber. With changing economic conditions and the onset of chestnut blight (caused by the fungus Cryphonectria parasitica) in the $20^{\text {th }}$ century, chestnut cultivation lost almost all of its economic and cultural significance.

In the last 20 years, there has been a renewed interest in preserving and replanting chestnuts. Today, this includes marketing strategies, landscape conservation and cultural history aspects. As chestnut cultivation is widespread, especially in the southern part of the Alps, its study provides links between landscape ecological research and sustainable development. This article describes different types of chestnut use and the characteristic landscapes thus generated as well as some aspects of biodiversity and landscape protection involved in the sustainable revaluation of that endogenous rural resource. The focus is on the role of the various actors, parks, regional planning, conservation and agricultural authorities as well as private organizations.
Profile

Landscape protection

Mountain range

Southern Alps

\section{Introduction}

Sweet chestnut (Castanea sativa, Fagaceae), a deciduous tree that produces amylaceous nuts, is the only European representative of its genus (Figure 1). In 15 Western and Southern European countries Castanea sativa is cultivated on ca. 2 million ha for production of its edible nuts and timber (Morandini 1959; Amorini et al. 2000; Conedera et al. 2004b). In many regions chestnut orchards and coppices have shaped the traditional cultural landscape threatened by abandonment in the course of the $20^{\text {th }}$ century (Ostermann 1998). The Habitats Directive is the central legal instrument of the EU for implementing obligations to protect biodiversity (CBD, Rio 1992). Annex I to the directive lists the habitat type "Castanea sativa woods" (code 9260), and the EUNIS biodiversity database contains the category "Castanea sativa-dominated forests and old established plantations with semi-natural undergrowth". Neither classification distinguishes cultivated woodland from natural Castanea forest. The term biodiversity includes several levels, encompassing variation of genes, populations, species, habitats and landscapes. Thus we have to consider different types of forests and plantations and their successional stages, as well as the different (genetic) varieties of Castanea sativa. Beyond their conservation value, the sweet chestnut stocks are relevant in terms of cultural history, landscape aesthetics and economy. Individual assessments of the stocks vary greatly depending on the type and

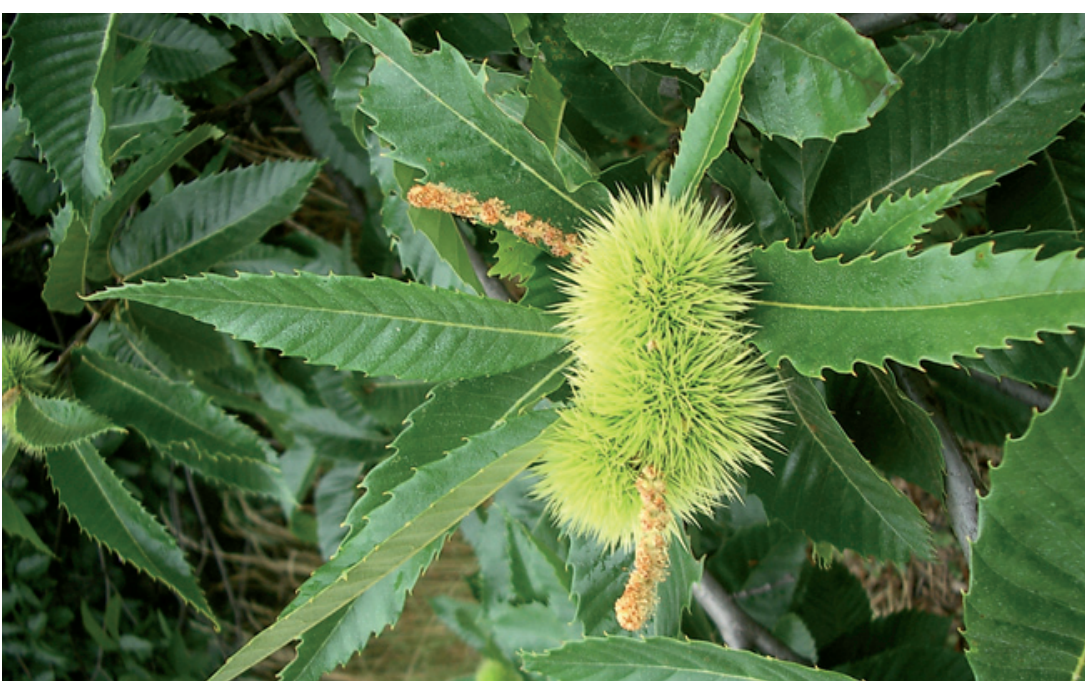

Figure 1 - Leaves, fruits and infructescence of Castanea sativa MILL.

extent of their use. Sustaining habitat diversity, i.e. the various sweet chestnut cultures, not just the Castanea sativa dominated mixed forests, is only achievable and feasible if their continued use can be safeguarded. Thus sustainable development of chestnut systems should rely on methods and insights from regional development research.

Based on an account of the origins and history of chestnut cultures in the Southern Alps, this article points out that chestnut stands deserve protection today. What has been missing so far is a survey of the current state of chestnut cultivation, including its 


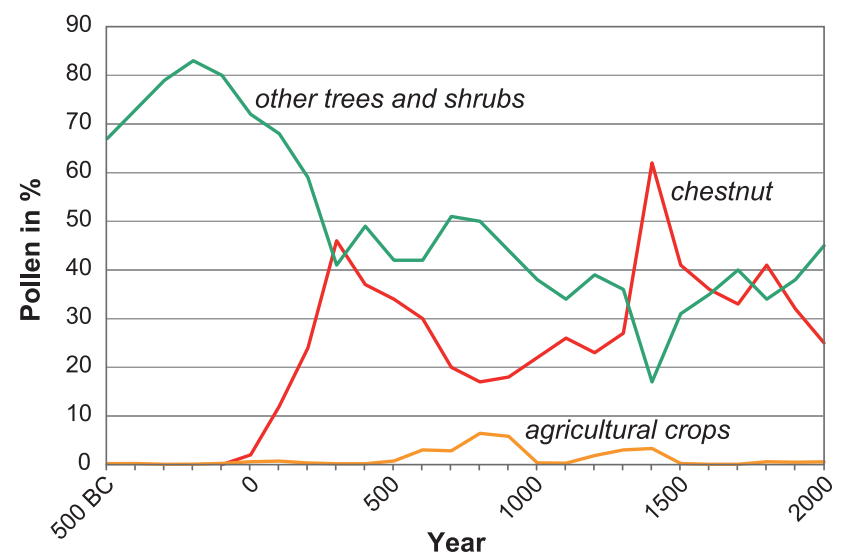

Figure 2 - Simplified pollen diagram of Lago di Origlio (Ticino), $420 \mathrm{~m}$ (acc. to Zoller 1961 and Tinner et al. 1999)

socio-cultural and socio-economic basis. Particular attention is devoted to the question how and why the appreciation of endogenous rural resources has been achieved with greatly varying success across the regions. Castanea sativa is distributed in all French, Italian and Slovenian parts of the southern alpine rim - with the core area clearly in the Maritime Alps (Southern Piedmont and Liguria; Table 1). Three regions in the Southern Alps with greatly differing socio-economic development (type, extent and social significance of their chestnut culture) over the last few centuries were selected for this study. Even today they take quite different political-administrative approaches towards protecting and revitalizing the Castanea sativa stocks. They are south-western Piedmont (Provincia di Cuneo, Italy), southern Switzerland (Canton Ticino and the southern valleys of Canton Grisons) and South Tyrol (Autonomous Province Bolzano, Italy). The paper is based mainly on open stakeholder interviews and on analyses of official documents. Both activities have been conducted consistently since 2001 .

\section{Chestnut culture and colonization process}

As early as the Miocene period, the chestnut was native on the European continent (Villani et al. 1994). There is a debate on whether it retreated to Caucasia during cold periods or whether it survived as a relic in northern Italy (cf. Krebs et al. 2004; Hofstetter et al. 2006). In any case, it spread throughout the Mediterranean region and across Europe some 2600 years ago alongside the Phoenician, Greek and Roman cultures (cf. Pitte 1986; Conedera et al. 2004b). During the first century AD, the Insubrian region (Ticino and north-western Lombardy) may be considered "the first centre of chestnut cultivation" (Conedera et al. 2004a: 173); here the chestnut became the dominant tree species and culture, replacing cereal farming and viticulture in many parts. The debate about whether Castanea sativa is an "honorary native or an alien species" (cf. Buckley \& Howell 2004: 5) arises from this extensive colonization.

After the demise of the Roman Empire, however, there was a hiatus in the development of the cultural landscape as the Germanic invaders at first supplanted chestnut cultures with arable farming. Not until the great increase in population and settlement density, even in higher valleys, from the $13^{\text {th }}$ to the $18^{\text {th }} / 19^{\text {th }}$

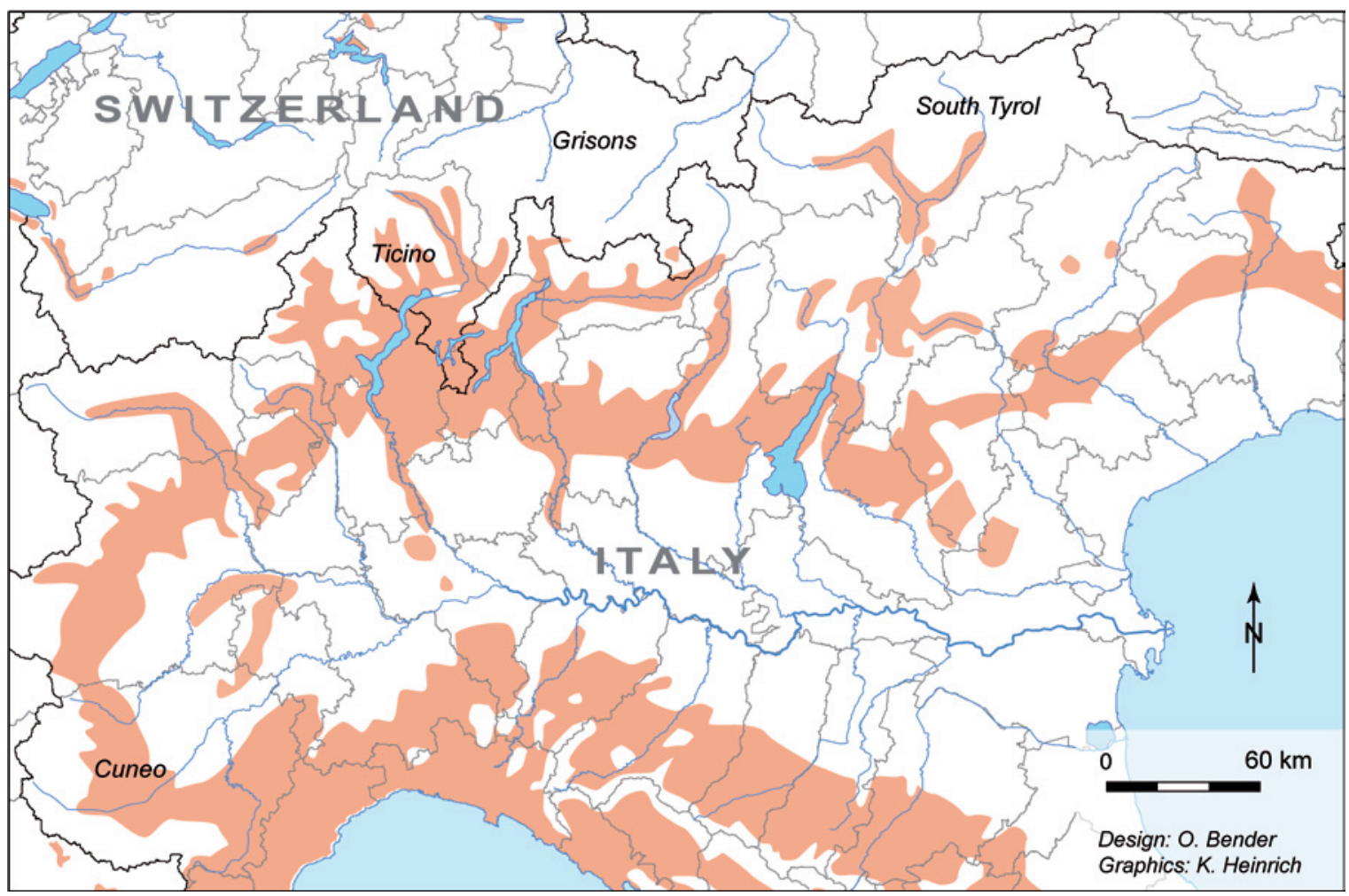

Figure 3 - The chestnut areas (indicated in apricot) in northern Italy and southern Switzerland, including scattered orchards and trees in mixed forests (acc. to Fenaroli 1945, slightly adapted) 


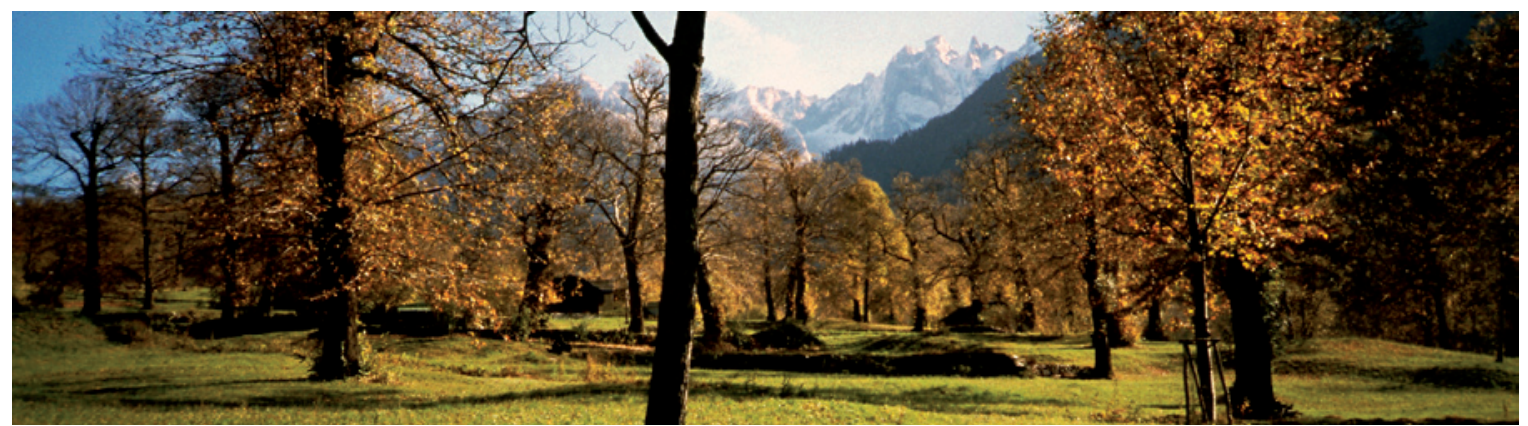

Figure 4-Chestnut orchard in the Castasegna area (Grisons)

century, did the sweet chestnut regain its status as the staple food of the Southern Alpine population (Zoller 1961; Figure 2).

The regional distribution of the sweet chestnut in the south-western Alps is mainly confined to a belt in the colline and submontane altitudinal zone at around $400-1000 \mathrm{~m}$ (Figure 3). This pattern of distribution suggests a special adaptation of nature: the chestnut is grown mainly on moderately acidic soil, under a temperate-humid climate, where steep slopes and rocky soils do not allow more intensive forms of land use (cf. Mayer 1986). In human ecology, "colonization" means a bundle of specific interventions in natural processes geared towards changing natural systems and processes in order to make them more useful to society than they would be in their natural state (Fischer-Kowalski \& Haberl 1998).

There are two basic types of chestnut use. The first, the chestnut orchard or selva, serves to produce fruits (Figure 4). In many valleys of the Southern Alps the chestnut took the place of the bread crop, especially for the poorest class. In regional languages the chestnut was l'arbur, the tree, and the grove was la selva, which means "the forest par excellence" (Conedera 1996). One tree was enough to produce $75-100 \mathrm{~kg}$ of nuts a year. Adequately preserved, this could feed $1-2$ people over a long winter (Merz 1919; Kaeser 1932). Different uses (flour, dried nuts, fresh nuts, etc.; Figure 9) resulted in the selection and breeding of a striking richness of varieties (cf. Bounous 2002); on the southern side of the Swiss Alps alone, more than 100 sweet chestnut cultivars have been recorded (Conedera 1994). Thus a genre de vie in the sense of Vidal de la Blache (1911) was established, in Italian called la civiltà del castagno (Bignami \& Salsotto 1983). In this spirit, the forms of settlement, the working rhythm throughout the year and the tradition and customs were mainly influenced by the chestnut. Even today, chestnut orchards form park-like landscapes with an aesthetic appeal. After the traditional Roman law, the singular trees with a so-called ius plantandi - often assigned to the tree - were owned by different families (Giardina 1941; Figure 5) while the meadows on which they stood belonged to the community.

The second traditional type of chestnut use is as coppices, the paline (Figure 6), widespread for timber production (cf. Bourgeois 1992). Due to the large proportion of tannin, chestnut timber is very durable without the need for preservation, has very good technical qualities and is easy to process. However, due to the ring shakes (tangential separations of the wood fibres along parts of the annual rings), the proportion of high-quality timber is below $25 \%$, leading to a bad product image (Giudici 1995). Chestnut timber is traditionally used as poles in viticulture, as water fences as well as firewood, also for char-burning. Furthermore, one should mention tannin production, which started in factories at the end of the $19^{\text {th }}$ century and was mostly abandoned in the 1960s when chemical tanning agents were invented (Bignami \& Salsotto 1983). Between selva and palina there are some transient forms like the coppice-shoots sprouting from the stumps of felled fruit trees.

\section{Distribution in the study areas}

In the south-western Piedmont, the chestnut area is situated mainly along the Alpine rim. Here chestnut trees make up about $15 \%$ of the total forest area, sometimes across more than $30 \%$ of the municipal areas. It has the de facto status of a monoculture. Of 25000 ha high stem cultures, 15000 ha are used as fruit cultures, 10000 ha of grafted plants have reverted to the wild. In addition, there are about 10000 ha of coppices. In terms of ownership, small and very small holdings prevail (90\% are less than 3 ha; Bounous 1999).

From the $16^{\text {th }}$ century onwards, the chestnut fruit surplus in Cuneo was snapped up by brokers and carried to the regional markets. With orientation to the markets, the Roman ius plantandi was given up in favour of plots and land ownership by the farmers. During the

Table 1 - Extent and fruit production of chestnut orchards in the Southern Alpine regions (acc. to Bounous 2002, Schweizerisches Landesforstinventar 1988*, FAOSTAT**)

\begin{tabular}{|l|r|r|}
\hline Region & Orchards 1996 (ha) & Fruit production 1997 (t) \\
\hline Liguria & 14597 & 199 \\
\hline Piedmont & $\mathbf{2 7 5 0 0}$ & $\mathbf{7 5 5 3}$ \\
\hline Val d'Aosta & 1985 & 57 \\
\hline Lombardy & 6437 & 836 \\
\hline Trentino-South Tyrol & $\mathbf{2 3 7}$ & $\mathbf{2 4 2}$ \\
\hline Veneto & 1904 & 141 \\
\hline Friuli-Venezia Giulia & 2200 & 73 \\
\hline Ticino/Grisons (*1988/**1999) & ${ }^{* 1400}$ & ${ }^{* *}<\mathbf{2 0 0}$ \\
\hline
\end{tabular}




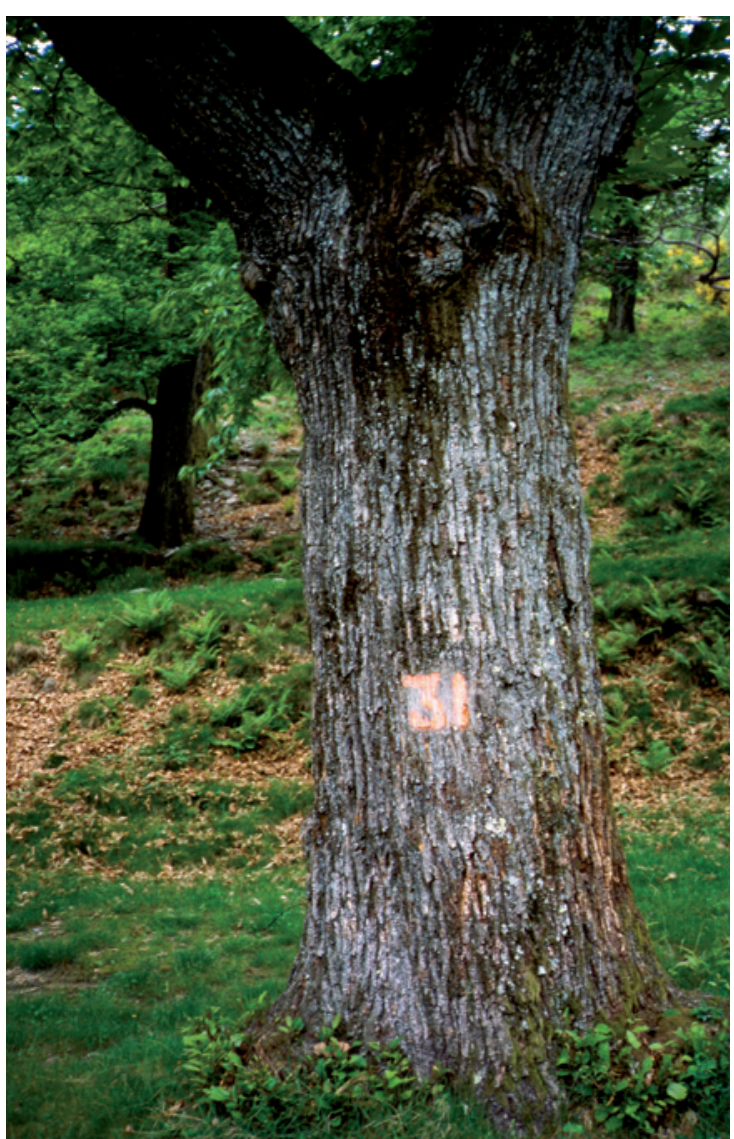

Figure 5 - Ius plantandi indicated by the family number in a selva in the Malcantone district (Ticino)

$19^{\text {th }}$ century, the township of Cuneo became an international trading place and the sales were made mostly during a trade fair at Martinmas. Currently the total harvest stands at $8500 \mathrm{t}$ a year, that is $12 \%$ of the Italian and almost $2 \%$ of world production (Bounous 1999). Traditionally, there are three sub-segments of the production and the market because most of the cultivars are spread regionally:

- the export-oriented market for fresh fruits of high quality, especially marroni, originating from the valleys near Cuneo;

the market for small dried fruits produced in the south-east of Cuneo province and refined in local mills;

and finally, the market for technically refined products such as confectionery.

Moreover there are large timber processing plants such as Borgogno Legno in Borgo San Dalmazzo, as well as a tannin factory (La Silva in San Michele Mondovi).

In Lombardy and neighbouring Italian-speaking southern Switzerland, the chestnut belt runs deep into the transverse Alpine valleys. Along the valley sides in the canton of Ticino there are 24000 ha of coppices, usually dominated by chestnut, only 1400 ha are selve (Table 1). In mountain areas, ca. $80 \%$ of the forest is owned by communes of citizens (patriziati). The traditional legal form of ius plantandi is expiring today (Conedera 1996). The orchards were fundamental for food supply during the winter season, indicated by the widespread drying kilns. Here, the marketing of chestnut fruits and products traditionally was less important. On the other hand, Switzerland is a big importer of Italian chestnuts (Bignami \& Salsotto 1983). Of course, the wholesale trade resides in Italy, but the wholesalers were mostly originating from Ticino. And, interestingly, the tradition of selling hot chestnuts in the streets of European city centres was created by people originating from the Blenio valley in Ticino (Conedera 1996).

Further east, the ribbon-like chestnut area dissolves into individual patches. In South Tyrol, the sweet chestnut often only forms a local belt between fruit orchards and forest (cf. Peer 1991; 1995). Ownership of the chestnut groves must be seen in connection with the closed farm according to Tyrolean law: the groves are small, scattered and usually individually owned. The distribution statistics in South Tyrol refer to a count of individual trees: there are ca. 30000 fruit trees in about 1800 sites with about 1300 owners. According to forestry statistics, the chestnut accounts for $8 \%$ of deciduous trees and $0.3 \%$ of the total forest stock. It mainly occurs, however, as coppice shoots in mixed coppices on steep lower slopes in the valleys. As a rule, chestnuts were only added occasionally to the staple diet because of the more generously proportioned undivided Tyrolean farm type of the Erbbaubof. This is also true for the moraine areas of the pre-Alps, if arable farming yielded good returns. In South Tyrol the annual production of ca. $400 \mathrm{t}$ today ends up entirely in personal consumption. Similarly to western Styria, a tradition of Törggelen (offering young wine and chestnuts in late autumn) has developed. There are no drying huts; these days chestnuts must be bought in from Tuscany and Piedmont (de Rachewiltz 1992).

\section{Causes and course of decline}

In the $19^{\text {th }}$ and $20^{\text {th }}$ centuries, the chestnut culture underwent a considerable loss of significance. In the beginning, the chestnut as a necessary staple food could be replaced by other, new, fruits like the potato. Later, the self-sufficiency economy was given up in favour of an inter-regional exchange of goods, mainly supported by the new rail routes. Emigration from the mountain areas reinforced this trend. After World War II, changed eating habits endowed the chestnut with a more negative image as a fruit for poor people. Thus, Italy's fruit production declined from $600000 \mathrm{t}$ in 1910 to only 38800 t in 1985 (Bignami \& Salsotto 1983; Bounous 2002). Within the Alps, only the export market for marroni from Cuneo remained essentially unaffected.

The decline in consumption mainly hit the market for "white chestnuts", i.e. dried fruit and flour. As early as the $19^{\text {th }}$ century, many chestnut stocks in the Piedmontese plain were changed into market-oriented cultures with a shorter turnover (Bignami \& Salsotto 1983). Later the competing intensive fruit cultures pushed 
in South Tyrol in places even beyond the upper cultivation limits of the chestnut. In Ticino and Grisons, however, Swiss forest regulations forbid actively changing the stocks. Here the chestnut fruit production virtually expired in the 1960s, so that of 9500 ha of selve (Merz 1919) only 1400 ha remained (Table 1). As a result of neglect and return to the wild, most fruit groves developed into mixed forests (Conedera et al. 2001; Stanga 1995). From the end of the $18^{\text {th }}$ century and in parallel to the rise in population and to industrialization, the demand for firewood, charcoal, and later also tannin, increased and more and more chestnut selve were changed into coppices (Table 2). From the 1960 s, however, the traditional wood products too lost their economic significance in favour of new fuels and tanning ingredients as well as concrete posts for viticulture. Since then, the turnover of chestnut coppices has ceased in many places.

Table 2 - Extent (in $\mathrm{km}^{2}$ ) of chestnut cultures in Italy (acc. to Bignami \& Salsotto 1983, Amorini et al. 2000)

\begin{tabular}{|l|l|l|l|l|}
\hline Year & 1939 & 1960 & 1980 & 1993 \\
\hline Orchards & 4750 & 4240 & 3171 & 2091 \\
\hline Coppices & 3160 & 2990 & 3655 & 3753 \\
\hline Total & 7910 & 7230 & 6826 & 5844 \\
\hline
\end{tabular}

Another important factor was the diffusion of different pests, starting with the ink disease (Phytophthora sp.), a fungal disease of the tree roots. Then, due to increasing neglect of the grassland between the trees, the harvest was damaged by various fruit parasites. And finally, the chestnut cancer (Chryponectria parasitica) was introduced in 1938 by ship from America to Europe via Genoa. This fungus disconnects the transport of water in the vascular cambium and kills individual branches or the whole tree. Within about 50 years, the majority of European trees had become affected, fuelling fears of a total extinction of the chestnut like in America (Bounous 2002; Figure 7).

\section{Initiatives for revitalization and protection}

However, at the end of a decline that has continued for 100-200 years, these days not only the economic value of chestnuts counts but also the ecology, scenery and cultural history of chestnut orchards have been

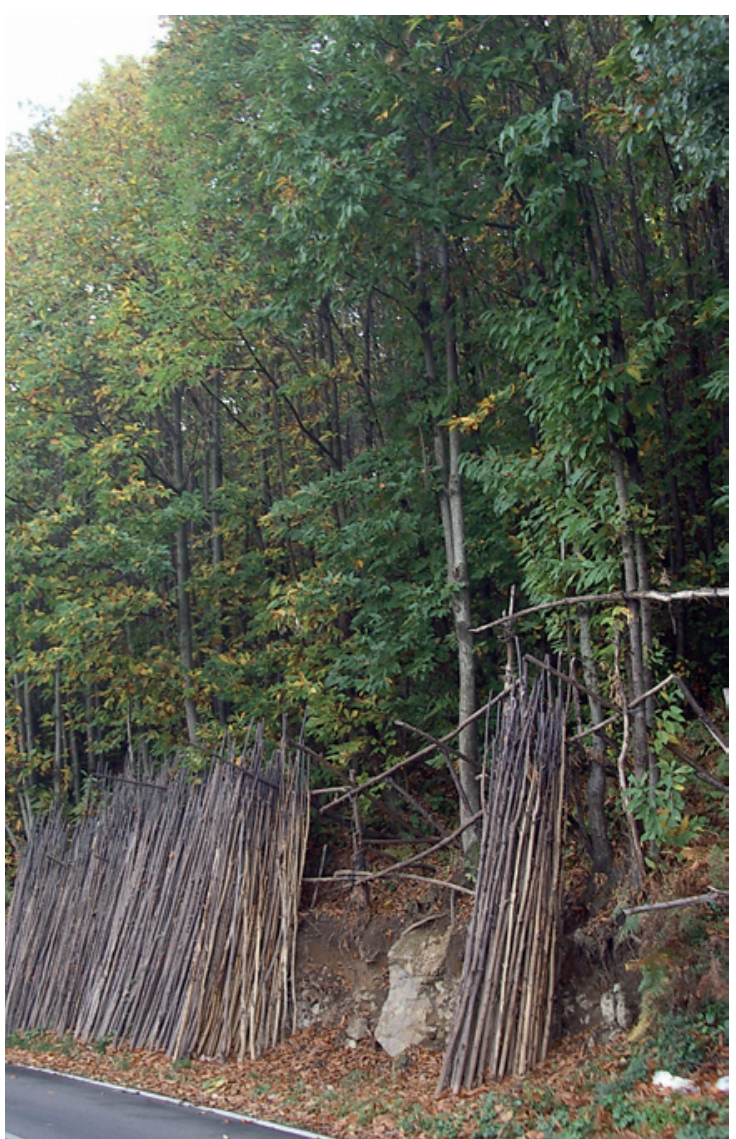

Figure 6-Chestnut coppice and poles for viticulture in the Agerola (Naples) area

recognized - be it as a native feature or as an attraction for tourists. One way of preserving these resources is to designate them formally as protected areas. This is a strategy mainly pursued in South Tyrol. Here the landscape plan opens up the possibility of taking stock and allocating the groves to various conservation categories, e.g. as "natural monuments" or "natural landscapes". In an effort to safeguard open spaces, cantonal forward planning in Grisons allows the designation of chestnut groves as "cultural landscapes of special cultivation". In the Italian Alps they often occur within larger protected areas, e.g. Val Grande National Park (Provincia del Verbano-Cusio-Ossola), Parco Regionale/Biosphere Reserve Campo dei Fiori (Provincia di Varese), Parco Naturale Alta Val Pesio e Tanaro (Provincia di Cuneo). There they are included in efforts to preserve biodiversity but at the same time

Table 3 - Extent and fruit production of chestnut orchards in Cuneo province (acc. to Bignami \& Salsotto 1983, Bounous 1999)

\begin{tabular}{|c|c|c|c|c|}
\hline District & Orchards 1975 (ha) & Orchards 1996 (ha) & Fruit production $1976(t)$ & Fruit production $1996(t)$ \\
\hline Gesso, Vermenagna, Pesio & 5447 & 3254 & 499 & 2500 \\
\hline Stura & 2684 & 2354 & 391 & 1800 \\
\hline Monregalesi & 9324 & 9000 & 1592 & 1000 \\
\hline Po, Bronda, Infernotto, Varaita & 4806 & 1225 & 1569 & 900 \\
\hline Maira & 931 & 400 & 261 & 150 \\
\hline Total & 36427 & 25444 & 6017 & 8400 \\
\hline
\end{tabular}




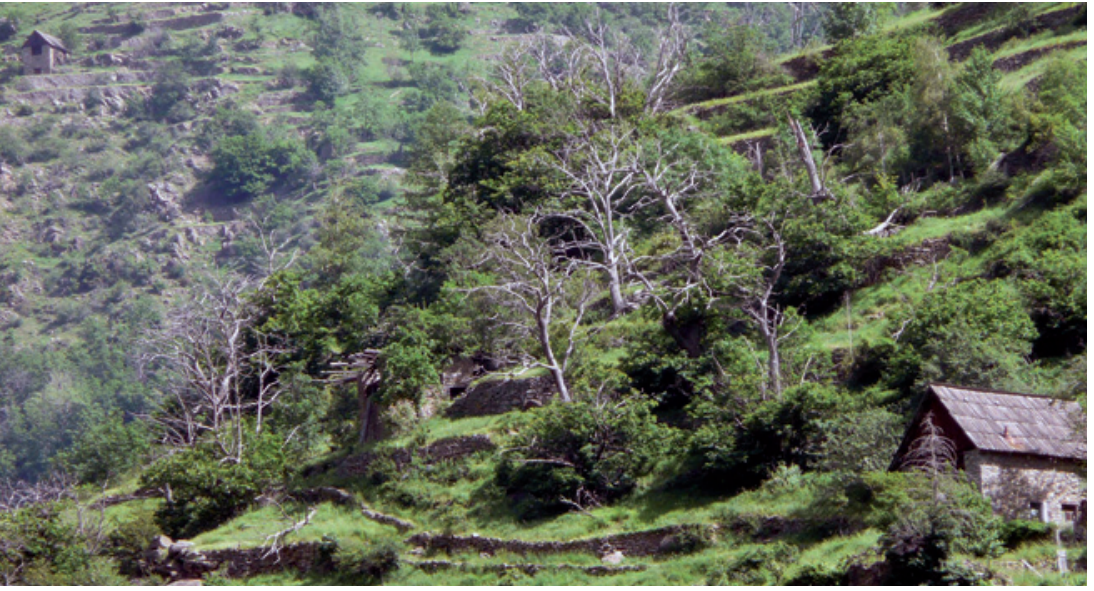

Figure 7 - Abandoned orchard with dead chestnut trees in the Tinée valley (Alpes Maritimes, France)
2006), with the different regional agricultural authorities mostly subsidizing $50 \%$ of the cost. In terms of fire prevention, too, ground cultivation in chestnut groves is desirable, as collecting leaf litter and mowing drastically reduce the threat of forest fires (Marxer et al. 1998).

There is no agreement on a general assessment of Castanea sativa in forestry terms: a purist conservation approach would demand its removal as an alien tree species. Developing mixed forests would necessitate elaborate human intervention as other timber species hardly manage to invade the dense chestnut coppice stocks (Conedera et al. 2000). Therefore forest management should be oriented towards a location-specific mix of tree species, which includes chestnut in suitable sites and takes account of owners' economic interests. In protected areas especially, chestnut stocks should be managed to protect biodiversity; management plans of parks need to be updated accordingly. Various studies (cf. Gondard et al. 2001; Moretti et al. 2004) have shown a relatively high level of biodiversity (of plants and several groups of animals, especially invertebrates and bats) in tended chestnut groves due to their open canopy and probably also due to frequent disturbance (e.g. pruning \& grazing). According to Gondard et al. (2006), mean plant diversity in the understorey of chestnut stands is even higher than in the oak stands they replace in many sites of this French study area. Generally, species richness is higher in well tended groves than in abandoned ones or in coppices, and thus "the abandonment of chestnut stands leads to homogeneous vegetation with decreasing diversity". However, conservation "of diverse chestnut stands modified by human activities (groves, cultivated or abandoned, and coppice stands) [...] could enhance regional plant diversity" (Gondard et al. 2006: 1129).

\section{Economic approaches}

Research on the economic potential of chestnut timber focuses on its quality potential. A systematic thinning of coppices, concentrating on $2-3$ shoots instead of on more than 20 , reduces the proportion of ring-shaked timber considerably (Fonti et al. 2002). Additional or recent forms of use are as material for avalanche fences and roofing shingles (Giudici 1996). Furthermore, in Bellinzona, a new thermal power station was constructed especially for chestnut firewood. Thus chestnut timber could increasingly substitute artificial or imported materials and demonstrate good examples for regional added value chains. Analyses of market potential are still needed. The overall objective of the Ticino forestry is to reach break-even point for chestnut firewood and to make a profit on the timber. Within the province of Cuneo, there are new intensively used orchards, mostly stocked with Euro-Japanese hybrids. Also, in Ticino, semi-intensive cultures are put to the test on former agricultural areas. However, these measures are in severe conflict with the ef-

forts to preserve the old chestnut orchards and their young chestnut trees (Figure 8). The costs amount to ca. 10000 EUR per hectare (cf. Rudow \& Borter 
variety of cultivars (Conedera 1994; Bounous 1999). In order to facilitate the harvest within traditional orchards, farmers in Cuneo have started using machines for collecting and sizing chestnuts (Bounous 1999). In Ticino, a centralization of harvest was organised - this means that a gathering point at the agricultural office has to buy all chestnuts at a fixed price. This was the only way of achieving a harvest volume worth marketing. In both regions, new methods of treatment, such as thermo-hydrotherapy and cold storage are put to the test in order to preserve the fruits to modern quality levels (Bounous 2002; Jermini et al. 2006).

The chestnuts are subjected to modern standards of marketing - which means that quality, homogeneity and an effective distribution chain are becoming ever more important. Many producers are handing their harvest over to cooperatives or wholesalers (Conedera 1996). Furthermore, traditional refined products such as chestnut bread, noodles, honey, beer and schnapps are being produced again (cf. Figure 9). Chestnuts may also provide a new basis for desserts and side dishes in autumnal restaurant cuisine. The people involved are convinced that only high quality regional products will be able to win over the younger generation of consumers. Efforts to obtain designations of protected origin (IGP Castagna Cuneo since 2007) must be seen in this context.

\section{Socio-cultural approaches}

Training courses are offered to farmers and refiners in order to spread the knowledge of a modern chestnut culture. Furthermore, newly created chestnut trails are addressing locals and tourists with interest in cultural history (e.g. Alto Malcantone in Ticino, Castasegna in Grisons, and Feldthurns in South Tyrol; Figure 10). In Cuneo province there are the "Chestnut Ecomuseum" in Boves and the recently designed "White Chestnut Tourist Route" to stimulate rural tourism and to provide good examples for regional economy. All over the southern part of the Alps, the traditional chestnut festivals in autumn (sagre, feste, fiere, etc.) were given up 30 or 40 years ago, and are now being re-established with support of most parts of the local population. In South Tyrol they were newly created on an Italian model. Finally, since 1999, the Fiera del Marrone, following the famous trade fair at Martinmas, was established as a supra-regional exhibition for crafts and trade of sweet chestnut products. The third Fiera in 2001 was dedicated to the themes of "Environment and Landscape", clearly showing the networking concept behind the efforts at revitalization.

\section{Networking of actors}

Finally, it is worth taking a look at the networks which are supporting the conservation and revitalization projects outlined above. In Ticino, these projects have been initiated by the "Swiss Federal Institute for Forest, Snow and Landscape Research" (WSL) and the forest administration, which are working together with

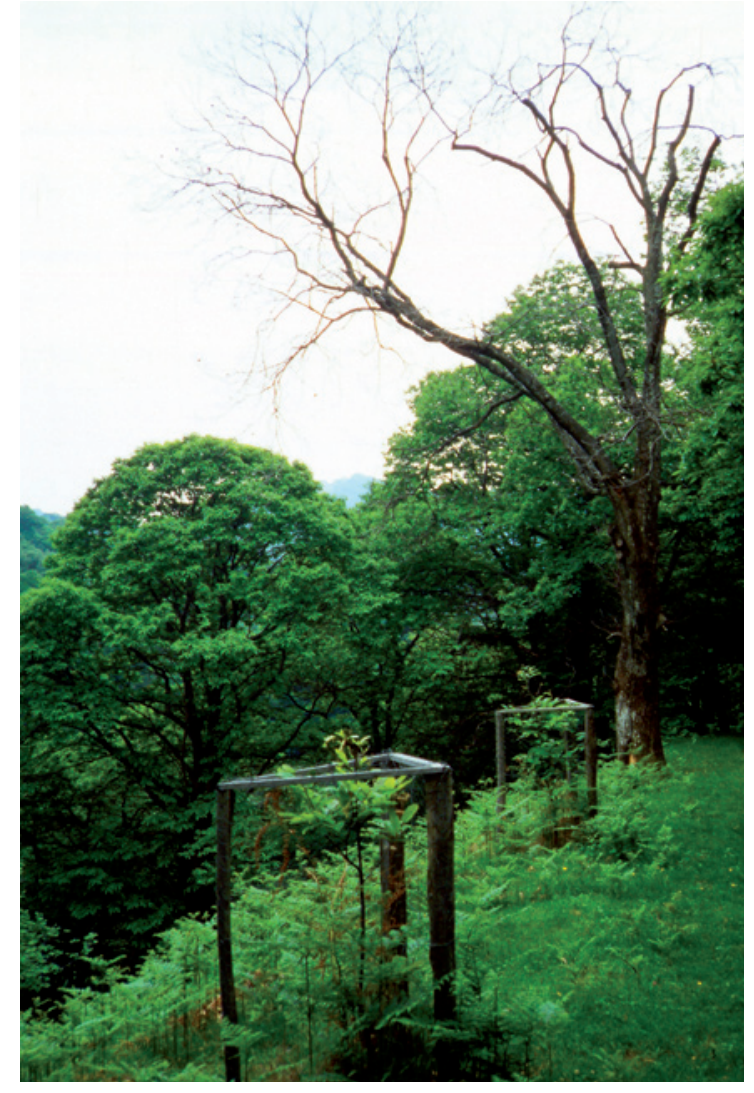

Figure 8-Dead and replanted chestnut trees in a selva within the Malcantone district (Ticino)

the agricultural research centre (RAC Cadenazzo). In 1991, an interdisciplinary working group (Gruppo Lavoro sul Castagno) was testing the economic efficiency of chestnut projects. In 1999, the "Association of Chestnut Farmers in the Italian Switzerland" was founded. From 1997 to 2001, the district of Malcantone was the precursor with a "Regio Plus-Project" that integrated landscape conservation, marketing, and tourist initiatives. In addition, various foundations (FLS/Swiss Landscape Fund, SL-FP/Swiss foundation of landscape protection and maintenance) funded up to $70 \%$ of the cost of local projects. From 2000 to 2006, the district of Malcantone continued it jointly with the Italian Parco Regionale Campo dei Fiori under the title La città del castagno as one of three Swiss-Italian INTERREG IIIA projects on chestnut culture.

In South Tyrol, authorities distributing regional funds (forestry administration and planning authority, fruit and wine-growing bodies, spatial management) are facing local initiatives. The association of chestnut farmers was subsumed into the "Working Group Sweet Chestnut" of the South Tyrolean Farmers Association (SBB). An important role in networking is played by local forest wardens, because they mediate between producers and the regional authority.

In Cuneo, since 1999, the "Association for the Revalorization of Chestnut" was responsible for developing and promoting chestnut culture at home and in other regions. The main aim was to create a powerful network by cataloguing all producers, retailers, refiners 


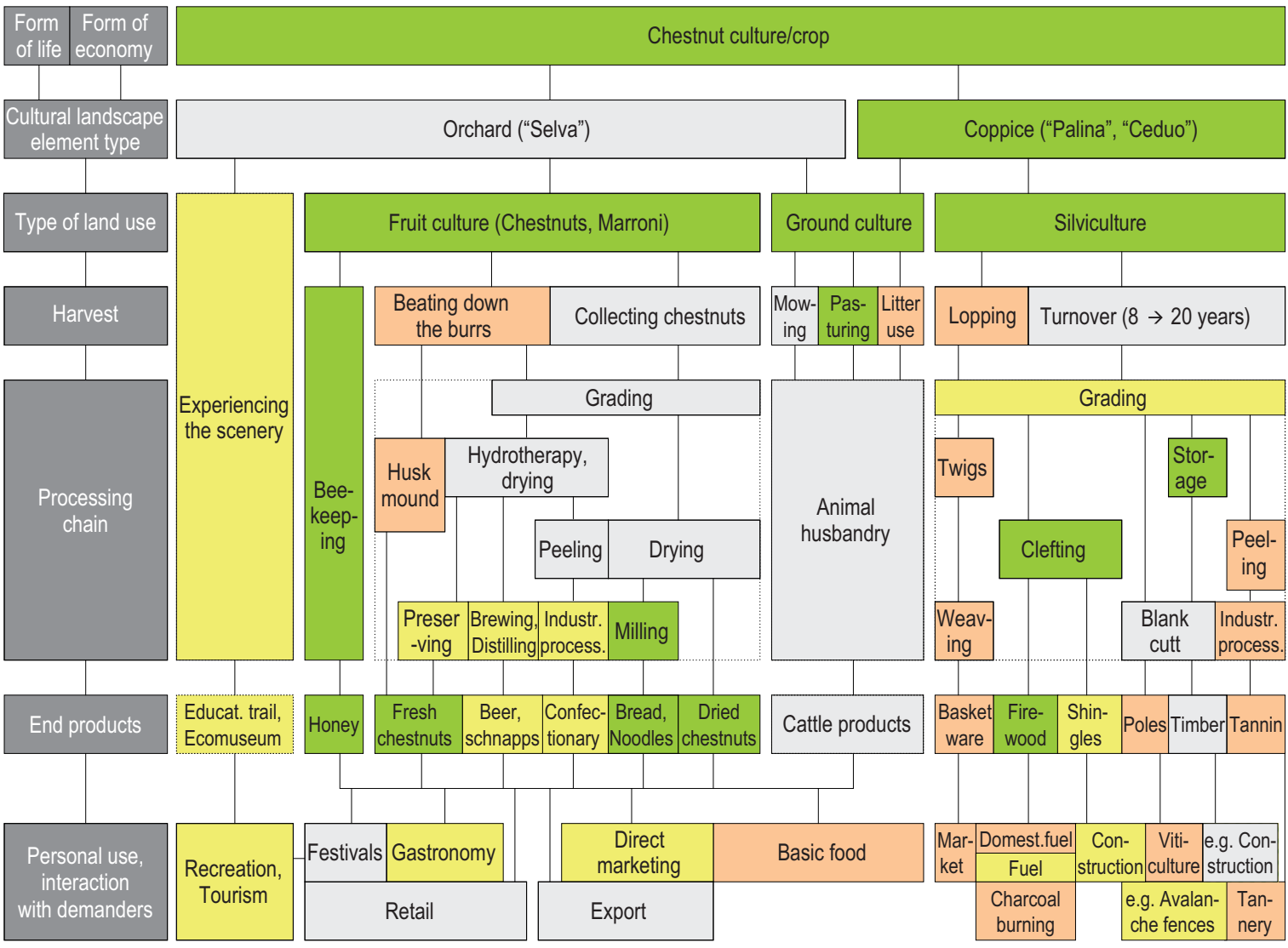

Figure 9 - A model of the chestnut economic system in the European Southern Alps: predominantly bistorical (red), traditional (green), new (yellow) elements, and traditional and new (light-grey) elements. C Oliver Bender

and restaurateurs, organizing the Fiera, etc. For several years, they strove to turn Cuneo into the "world centre of the chestnut" in economic and cultural terms.

\section{Conclusion}

Chestnut culture as a form of living (genre de vie) is clearly gone forever and of historical interest only. All the more so, new concepts of revitalization of the chestnut culture must be based on regional economic activities (production, trade, tourism) in order to achieve sustainability. In so doing they are using regional resources and capabilities (social asset):

- in Ticino mainly building on the tradition of selfsufficiency and on initiatives from forest research;

- in South Tyrol based on medium-scale mixed farms in the tradition of self-sufficiency and also on initiatives from forest research;

- in Cuneo mainly based on the small chestnut farms with their tradition of delivering to the market and on the initiative of a recently founded regional association.

These concepts may help to commercially activate a lot of areas which had previously lain fallow, thus adding a regional value. Furthermore, the preservation and the economic use of chestnut groves is advantageous for the ecology by reducing forest fires, strengthening the protective functions of the forest and keeping a high level of biodiversity. The energy input during grow- ing, conservation and refining is indeed higher than in the traditional self-sufficiency economy, but through regional production chains and economic cycles it is clearly less than what would be needed for the products which might replace the chestnut. Finally, in the socio-cultural domain a great deal is achieved - from keeping the regional identity to stimulating tourism, to maintaining a source of income, which stabilizes settlement. Thus, we can conclude that the new concepts of chestnut revitalization are endogenous and sustainable and they add significant value to the regional economy.

Largely based on agrarian and forest sciences, the quite intensive Italian and Swiss research on the revitalization of chestnut stocks focuses on biology and cultivation technology. Much less research (mainly in Ticino) has been devoted to interdisciplinary cultural landscape or regional studies, let alone to a cross-regional comparative perspective. Access to the data in the studied areas is however good enough to consider applying the new approaches to other regions (e.g. INTERREG IIIA La città del Castagno).

\section{Management implications}

After all, the effects of the different initiatives for preserving and managing Castanea sativa stocks still need to be evaluated. What are the unique contributions of protected areas, subsidies and con- 
tracts from agricultural, forestry and conservation authorities? How much economic value is added by new product chains and marketing campaigns? Are there conflicts between the different measures and how can they be integrated? And finally, is it feasible to encourage regional competition and/ or to support cross-regional networking?

Of course, the parks in the Southern Alps (e.g. Alta Val Pesio e Tanaro and Campo dei Fiori) are managing their chestnut stands autonomously. However, they might play an even more prominent role in bringing forth research and development of chestnut-related conservation and management strategies which should also be implemented in the relevant management plans. An outstanding example is the Parc naturel régional des Monts d'Ardèche in the French region Rhône-Alpes, which was founded on the initiative of regional chestnut growers.

\section{Acknowledgements}

The author would like to thank all the people and organizations who have helped make the study and the report possible. In particular he wishes to thank the Swiss Federal Institute for Forest, Snow and Landscape Research (WSL); Cantone Ticino; Regione Malcantone; L'Associazione per la valorizzazione del castagno, Cuneo; and Autonomous Province Bolzano. He would also like to express his sincere thanks to Marco Conedera, WSL, Bellinzona, and to Giancarlo Bounous, Università degli Studi di Torino, as well as to two unknown reviewers.

\section{References}

Amorini, E., G. Chatziphilippidis, O. Ciancio, F. Di Castri, F. Giudici, S. Leonardi, M.C. Manetti, S. Nocentini, M. Pividori, M., M. Rapp, F. Romane, E. Sevrin \& A. Zingg 2000. Sustainability of chestnut forest ecosystems: Is it possibile? Ecologia Mediterranea 26, 1-2: 3-14.

Bignami, G.R. \& A. Salsotto 1983. La civiltà del castagno. Cuneo.

Bounous, G. 1999. Tra i castagni del Cuneese. Cuneo.

Bounous, G. 2002. Il castagno. Coltura, ambiente ed utilizzazioni in Italia e nel mondo. Bologna.

Bourgeois, C. 1992. Lechataignier. Un arbre, un bois. Paris.

Buckley, P. \& R. Howell 2004. The ecological impact of sweet chestnut coppice silviculture on former ancient, broadleaved woodland sites in south-east England. English Nature Research Reports 627. Peterborough.

Conedera, M. 1993. Cancro corticale del castagno. Principali caratteristiche epidemiologiche e misure pratiche di controllo. Berichte der Eidgenössischen Forschungsanstalt für Wald, Schnee und Landschaft 335. Birmensdorf.

Conedera, M. 1994. Inventario e caratterizzazione genetica della varietà nostrane di castagno da frutto. Bollettino della Società Ticinese di Scienze Naturali 82, 2: 39-50.

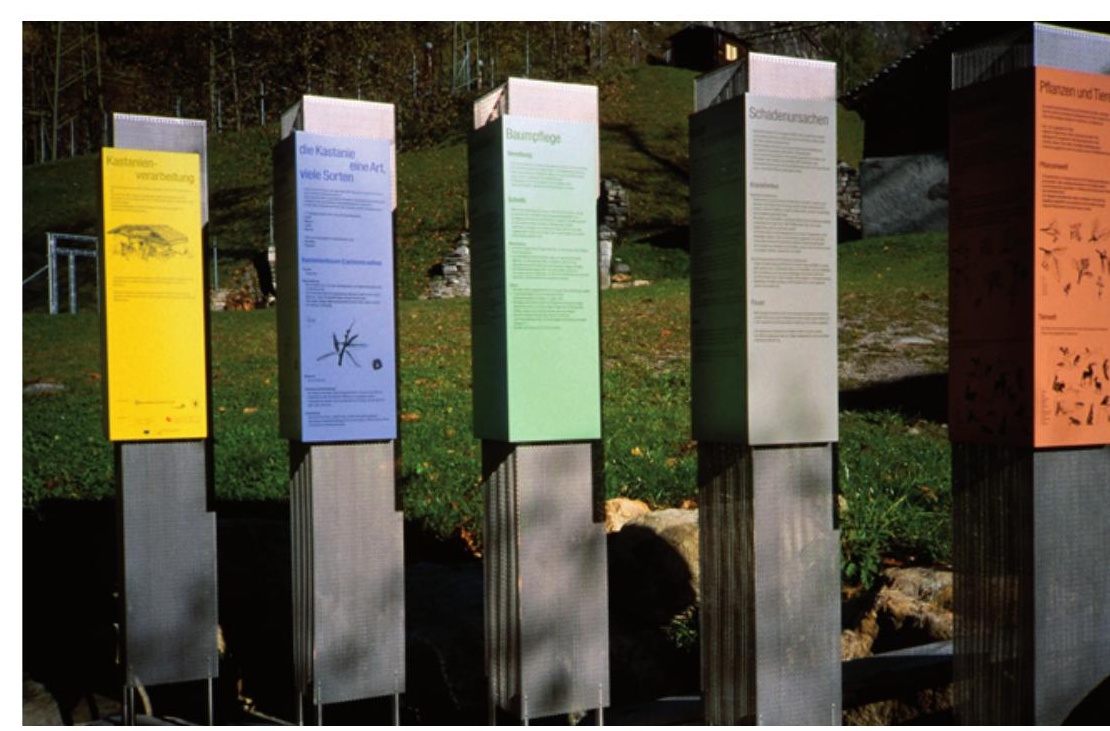

Figure 10 - Entrance of the chestnut trail in Castasegna (Grisons)

Conedera, M. 1996. Vergangenheit, Gegenwart und Zukunft der „Waldfrucht par excellence“. Bündnerwald 49, 6: 28-46.

Conedera, M., P. Krebs, W. Tinner, M. Pradella \& D. Torriani 2004a. The cultivation of Castanea sativa (Mill.) in Europe, from its origin to its diffusion on a continental scale. Vegetation History and Archaeobotany 13: $161-179$.

Conedera, M., M.C. Manetti, F. Giudici \& E. Amorini 2004b. Distribution and economic potential of the Sweet chestnut (Castanea sativa Mill.) in Europe. Ecologia Mediterranea 30, 2: 179-193.

Conedera, M., P. Stanga, Ch. Lischer \& V. Stöckli 2000. Competition and dynamics in abandoned chestnut orchards in southern Switzerland. Ecologia Mediterranea 26, 1-2: 101-112.

Conedera, M., P. Stanga, B. Oester \& P. Bachmann 2001. Different post-culture dynamics in abandoned chestnut orchards and coppices. Forest, Snow and Landscape Research 76, 3: 487-492.

de Rachewiltz, S.W. 1992. Kastanien im südlichen Tirol. Arunda 33. Schlanders.

Fenaroli, L. 1945. Il castagno. Trattati di agricoltura 1. Roma.

FAOSTAT. Available at: http://faostat.fao.org/ site/567/DesktopDefault.aspx?PageID=567\#ancor (accessed: 21.04.2010).

Fischer-Kowalski, M. \& H. Haberl 1998. Sustainable Development: Socio-Economic Metabolism and Colonization of Nature. International Social Science Journal 158, 4: 573-587.

Fonti, P., N. Macchioni \& B. Thibaut 2002. Ring shake in chestnut (Castanea sativa Mill.): State of the art. Annals of Forest Science 59, 2: 129-140.

Giardina, C. 1941. La cosiddetta proprietà degli alberi separata da quella del suolo in Italia. Atti della $\mathrm{R}$. Accademia di Scienze, Lettere ed Arti, IV, II, 2: 5-280.

Giudici, F. 1995. La valorizzazione del legname di castagno nel Cantone Ticino. Forestaviva 13: 80-87. 
Giudici, F. 1996. Scandole con il legno di castagno? Cantieri \& Abitare 96, 5: 63-68.

Gondard, H., F. Romane, M. Grandjanny, J. Li \& J. Aronson 2001. Plant species diversity changes in abandoned chestnut (Castanea sativa) groves in southern France. Biodiversity and Conservation 10: 189-207.

Gondard, H., F. Romane, I. Santa Regina \& S. Leonardi 2006. Forest management and plant species diversity in chestnut stands of three Mediterranean areas. Biodiversity and Conservation 15: 1129-1142.

Hofstetter, S., W. Tinner, V. Valsecchi, G. Carraro \& M. Conedera 2006. Lateglacial and Holocene vegetation history in the Insubrian Southern Alps - New indications from a small-scale site. Vegetation History and Archaeobotany 15: 87-98.

Jermini, M., M. Conedera, T.N. Sieber, A. Sassella, H. Schärer, G. Jelmini \& E. Höhn 2006. Influence of fruit treatments on perishability during cold storage of sweet chestnuts. Journal of the Science of Food and Agriculture 86: 877-885.

Kaeser, H. 1932. Die Kastanienkultur und ihre Terminologie in Oberitalien und der Südschweiz. Diss., Aarau.

Krebs, P., M. Conedera, M. Pradella, D. Torriani, M. Felber \& W. Tinner 2004. Quaternary refugia of the sweet chestnut (Castanea sativa Mill.): an extended palynological approach. Vegetation History and Archaeobotany 13: 145-160.

Marxer, P., M. Conedera \& D. Schaub 1998. Postfire runoff and soil erosion in the sweet chestnut belt of southern Switzerland. In: Trabaud, L. (ed.), Fire Management and Landscape Ecology: 51-62. Washington.

Merz, F. 1919. Die Edelkastanie. Ihre volkswirtschaftliche Bedeutung, ihr Anbau und ihre Bewirtschaftung. Bern.

Mayer, H. 1986. Europäische Wälder. Ein Überblick und Führer durch die gefährdeten Naturwälder. Stuttgart/New York.

Morandini, R. 1959. Notes sur la carte d'ensemble du châtaigner dans le pays de la région méditerranéenne. Rapport de la quatrième session de la Commission Internationale du Châtaigner, FAO. Rome: 55-57.

Moretti, M., D. Tonolla, I. Altenburger \& P. Duelli 2004. Biodiversità delle selve castanili del Monte Grand (Soazza, Grigioni). Quaderni grigionitaliani 73, 4: 355-362.

Ostermann, O.P. 1998. The need for management of nature conservation sites designated under Natura 2000. Journal of Applied Ecology 35: 968-973.

Peer, Th. 1991. Karte der aktuellen Vegetation Südtirols, Maßstab 1:200.000. Bozen.

Peer, Th. 1995. Die natürliche Pflan₹endecke Südtirols. Begleittext zur Karte der natürlichen Vegetation 1:200.000. Bozen.

Pitte, J.R. 1986. Terres de castanide. Homme et paysages $d u$ châtaignier de l'antiquité à nos jours. Paris.

Rudow, A. \& P. Borter 2006. Erhaltung der Kastanienkultur in der Schweiz - Erfahrungen aus 46 Selvenrestaurationsprojekten. Schweizerische Zeitschrift für Forstwesen 157, 9: 413-418.
Ryser, D. 1998. Il ritorno al castagno. Montagna 9, 4: 27-30.

Schweizerisches Landesforstinventar 1988. Ergebnisse der Erstaufnahme 1982-1986. Berichte der Eidgenössischen Anstalt für das forstliche Versuchswesen 305. Birmensdorf.

Stanga, P. 1995. Evoluzione naturale dell'area castanile. Forestaviva 13: 59-63.

Tinner, W., P. Hubschmid, M. Wehrli, B. Ammann \& M. Conedera 1999. Long-term forest fire ecology and dynamics in southern Switzerland. Journal of Ecology 87: 274-289.

Vidal de la Blache, P. 1911. Les genres de vie dans la géographie humaine. Annales de Géographie 111: 193212; 112: 289-304.

Villani, F., M. Pigliucci \& M. Cherubini 1994. Evolution of Castanea sativa Mill, in Turkey and Europe. Genetical Research 63: 109-116.

Zoller, H. 1961. Die kulturbedingte Entwicklung der insubrischen Kastanienregion seit den Anfängen des Ackerbaus im Neolithikum. Berichte des Geobotanischen Instituts der ETH Zürich, Stiftung Rübel 32: 263-279.

\section{Author}

\section{Oliver Bender}

Oliver Bender is a senior researcher at the Institute of Mountain Research: Man and Environment of the Austrian Academy of Science in Innsbruck. He studied geography in Erlangen and Bamberg, received his diploma and his $\mathrm{PhD}$ in geography from the University of Bamberg $(1993,1999)$ and his post-doc lecturing qualification ("Habilitation") from the University of Innsbruck (2006). His research interests include landscape, regional and urban development. He acted as the Austrian research coordinator in the COST Action 27 "Understanding pre-industrial structures in rural and mining landscapes (LANDMARKS)" and is the Austrian National Representative at "The Permanent European Conference for the Study of the Rural Landscape (PECSRL)".

All photographs (C) Oliver Bender 